\title{
JANEZ OREŠNIK ON HIS SEVENTIETH BIRTHSDAY
}

Over a career spanning some forty years, Janez Orešnik has quietly gone about the business of firmly establishing himself at home and abroad as a linguist at ease in diachronic comparative studies of Indoeuropean languages and descriptive studies of modern languages in the best of the structuralist tradition. In theoretical linguistics, he questions with insight what the generative wisdom of the day claims separates the particular from the universal in languages, whether phonological, morphological or syntactical. He is comfortable with twenty or so languages and is known graciously to engage guest speakers at conferences he hosts at the University of Ljubljana in their native languages. He makes a point of actively participating at the Monday meetings of the Ljubljana Linguistic Circle.

Such wide-ranging linguists do not appear frequently. Janez Orešnik, Professor of Germanic Comparative Linguistics and General Linguistics, member of Slovenian and European Academies of Sciences and Arts, founder and first Chair of General Linguistics at the University of Ljubljana, was born on 12 Dec. 1935, in Ljubljana. Here he received his basic undergraduate and graduate training in linguistics: in 1957, a B.A. in English language and literature, followed a year later with a B. A. in comparative linguistics of Indoeuropean languages. In 1965, he earned a Ph. D. in Germanic Linguistics. In 1961, he began his teaching career in the Department of Germanic Languages and Literatures at the University of Ljubljana and rose to the rank of full professor in 1982. Additionally, he has been both lecturer and visiting scholar at such major centers as Copenhagen, Reykjavik, Harvard, Madrid, Cambridge, Uppsala, Leipzig, Zagreb, Vienna, Klagenfurt, Salzburg, and Berlin.

Janez Orešnik first attained international recognition as an Indoeuropean comparative linguist. He established his reputation in northern Germanic comparative philology with a number of learned articles on the phonology, morphology, and morphosyntax of the old, modern, as well as on the substandard Icelandic language. A selection of these articles appeared in his 1985 collection Studies in the Phonology and Morphology of Modern Icelandic: a Selection of Essays.

Closer to home, Orešnik has also made it his priority to study the structure of his native Slovenian and establish the relevance of the Slovenian data he amassed for the study of general linguistics. He has investigated the structure of Slovenian from a broad typological perspective in a number of articles and monographs that provide insightful descriptions of Slovenian structure. With characteristic clarity, he has demonstrated how to proceed from a description of the observed property towards its explanation. In a number of articles, Orešnik demonstrates that description becomes explanation when it insightfully separates what in the phenomenon under study is idiosyncratic to a language or language type and what is universal. For this, he invariably selects the thorniest aspects of Slovenian structure. What immediately comes to mind is his treatment of the rise and structure of the socalled Wackernagel, or second-position clitics and the clitic string (cf. Orešnik 
$1983 / 84,1984,1984 b, 1984 / 85,1985 / 86)$. His overall approach is delineated in two more recent monographs on the structure of Slovenian. The 1992 collection, Udeleženske vloge v slovenščini $=$ Semantic Roles in Slovene, brings together Orešnik's attempts to construct algorithms for automatic recognition of such syntatic properties of Slovenian structure as assignment of semantic roles to noun phrases at sentence and phrase levels, determination of the antecedents of anaphoric expressions, including reflexives, as well as interpretation of the unexpressed subject of infinitives and supines. The 1994 collection, Slovenski glagolski vid in univerzalna slovnica = Slovene Verbal Aspect and Universal Grammar, is a collection of his more recent typological inquiries.

His central interest in linguistic approaches that promise fresh insights into the structure of human language led him to introduce to Slovenian linguists at its inception Noam Chomsky's generative theory of language. In a number of articles addressed to the general reader (cf. among others, Orešnik 1967) Orešnik clarifies the aims and methodology of emerging linguistic research and invites Slovenian linguists to join a growing generative linguistic audience with transformational-generative descriptions of Slovenian grammar. A number of articles delineate Orešnik's critical appraisal of some of the early formal properties of transformational generative grammar (cf. for example Orešnik 1968). The pioneering 1972 monograph Language-particular rules and explanation in syntax, in co-authorship with David Perlmutter, is the earliest transformational-generative treatment of any Slovenian syntactic phenomenon. The monograph shows Orešnik at his best. He selects, seemingly at random, a highly restricted phenomenon in Slovenian grammar, in this instance the so-called orphan accusative of inanimate masculine and neuter noun phrases, and then proceeds to demonstrate that although the phenomenon can be formalized in a number of ways, only some will approach explanatory adequacy.

His interest in language universals and language typology continue to be the highpoints of Orešnik's approach to linguistics. His approach goes beyond the matter of universal grammar, as conceived, for example, in Noam Chomsky's generative theory of language. Orešnik holds with the theory of naturalness, which had its origins in Austrian and German universities and linguistic roots in the concepts of markedness and iconicity. Once we have gained an initial understanding of the structural properties languages must or cannot have, we can proceed to explore which of the permitted properties are in fact preferred. For the past decade or so, Orešnik has been developing, together with a group of Slovenian linguists, the Slovenian extension to the naturalness theory at the syntactic level (1999, Krepke in sibke dvojnice $v$ skladnji $=$ Strong and weak variants in syntax; 2001, A Predictable aspect of (Morpho)syntactic variants = Predvidljiv vidik (obliko)skladenjskih dvojnic; 2004, Naturalness in (morpho)syntax : English examples $=$ Jezikovna naravnost $v$ (obliko)skladnji: angleški zgledi.

Orešnik's influence in linguistics has been decisive. There is hardly a linguist who has not profited from his long and distinguished presence in the field. As Chair 
of the Department of Comparative and General Linguistics at the University of Ljubljana, over a span of some thirteen years, he has not only fashioned a varied linguistics curriculum, but has as well guided a number of graduate students to pursue linguistics as a professional discipline, as I personally can attest. That Janez Orešnik is being signally honored in this Festschrift, with its wide range of approaches to linguistics by distinguished contributors, at once testifies to his notable achievements in the profession.

Marija Golden 